\title{
Vergrijzing sterker in kleine gemeenten
}

HANNA VAN SOLINGE, NIDI

In absolute aantallen wonen de meeste ouderen in de grotere steden, en dan vooral in de Randstad. Relatief gezien is het aandeel ouderen echter het grootst in de kleinere gemeenten en de minst verstedelijkte gebieden. $\mathrm{Zo}_{\mathrm{o}}$ ligt het percentage 6o-plussers in de vier grote steden in Nederland op 17,4, terwijl in de kleinste gemeenten ongeveer 3 op de Io in- woners ouder is dan 60 jaar. De 'jongste' gemeente in Nederland is Urk, met een gemiddelde leeftijd van 3I,6 jaar, de oudste gemeente is Laren $(\mathrm{NH})$ waar de inwoners gemiddeld nog net geen Abraham of Sara zien (49, I jaar). In Laren is een op de ro inwoners ouder dan 80 jaar, tegen I op de 50 in Urk.

\section{Vergrijzing naar gemeentegrootte, 2015}

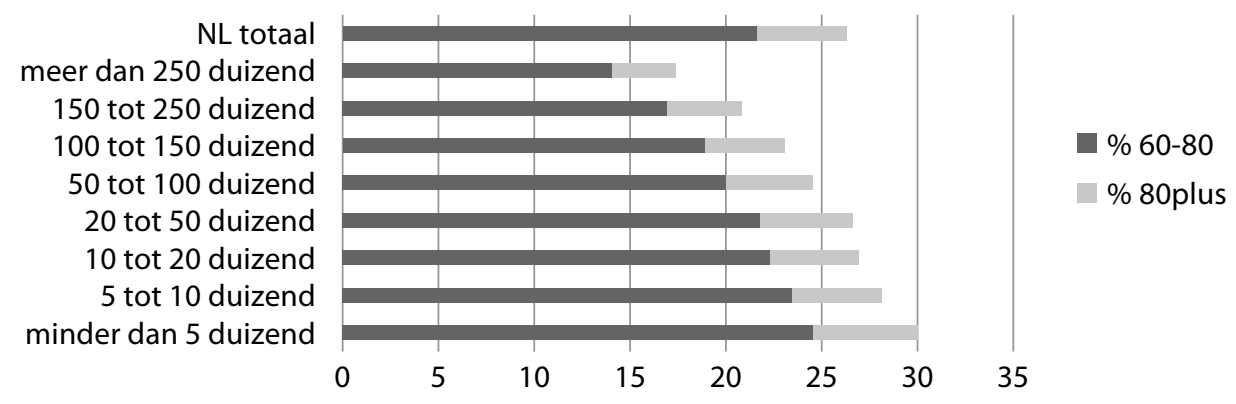

De minst en meest vergrijsde gemeentes in Nederland (in $\% 60-80$ jarigen en 80 -plussers)

\begin{tabular}{llll}
\hline & Minste 60-80 jarigen & & Meeste 60-80 jarigen \\
\hline Urk & 10,4 & Blaricum & 30,6 \\
Utrecht & 11,3 & Bergen (NH.) & 30,1 \\
Almere & 12,7 & Vaals & 28,3 \\
Zeewolde & 13,2 & Schiermonnikoog & 28,2 \\
Groningen & 13,5 & Bellingwedde & 28,0 \\
& & & \\
\hline
\end{tabular}

\begin{tabular}{llll}
\hline & Minste 80-plussers & & Meeste 80-plussers \\
\hline Urk & 1,8 & Laren & 10,2 \\
Almere & 2,0 & Roozendaal & 8,6 \\
Lelystad & 2,3 & Haren & 8,5 \\
Zeewolde & 2,5 & Bloemendaal & 8,2 \\
Utrecht & 2,6 & Wassenaar & 7,8 \\
Nederland & 21,6 & Nederland & 4,7 \\
\hline
\end{tabular}

